\title{
EVAPORATIVE CONDENSER PERFORMANCE ANALYSIS IN VCRS WITH R-134A AS REFRIGERANT
}

\author{
Bairi Levi Rakshith \\ Dept. of Mechanical, CBIT \\ Hyderabad
}

\begin{abstract}
The consumption of electrical and thermal energies by appliances in the residential building sector is growing fast and lots of methods are being followed to beat the energy demand in this sector. Among the various approaches, performance enhancement of refrigeration systems has been recognized as one of the important areas for investigation. Due to the increase in the use of small-scale applications and their effect on global energy requirements, specific research has to be focused on small-scale systems with water-cooled condensers to reduce energy usage in residential buildings. In this study, the evaporative condenser of a refrigeration system was connected to the prevailing water distribution with a submerged motor. The proposed system was analysed for energy savings, performance enhancement, and environmental benefits.
\end{abstract}

Key words: R134-a, COP, EVAPORATIVE CONDENSER. VCRS

\section{INTRODUCTION}

Renewable energy consumption reduction is a critical goal for reducing global warming. Vapor compression devices for homes may be found all around the globe. Any effort to reduce these devices' energy usage will reduce their reliance on fossil fuels. The COP, which is increased by lowering the condensing temperature, determines how much energy these units use. Because water has a higher heat transfer coefficient than air, evaporative cooled condensers are often employed in big components. As a result, it absorbs more heat than an air-cooled condenser. The refrigeration effect is also increased by subcooling the refrigerant below its liquid saturation temperature. As a result, the system's COP rises [1-4]. The performance of a vapour compression refrigeration system with an evaporative condenser and silver alloy in the lubricant was studied in order to reduce compressor effort and boost system cop. The Evaporator, Compressor, and Evaporative Condenser, Heat Exchanger, and Expansion Valve make up the Modified Refrigeration Cycle. A heat exchanger is put between the condenser and the evaporator, as

\author{
Dr. Shesha Giri Rao \\ Dept. of Mechanical, CBIT \\ Hyderabad
}

well as a Nano lubricant in the compressor, to accomplish the sub-cooling process. Heat is transferred from a high-temperature liquid refrigerant to a low-temperature vapour refrigerant in the heat exchanger, and the liquid refrigerant is sub-cooled. As a result, the compressor's workload is decreased $[5,6]$.

\section{SYSTEM DESIGN AND EXPERIMENTAL SETUP}

The performance of a home refrigerator with a 165liter capacity and an evaporative condenser system utilising R134a, as well as a heat exchanger between the condenser and the evaporator for subcooling and superheating, is investigated. The R134a Compressor, Proposed Evaporative Condenser, Submersible Pump Motor, and Aluminium Sheets are the main components of the tested refrigeration cycle's architecture. A set of tubes make up the evaporative condenser. The fluid in one pair of these tubes is heated or chilled. The second fluid that goes through the tubes is heated or cooled, depending on whether it supplies or absorbs heat. Copper is used for the condenser, which is placed lengthwise in a water tray with a shallow water. The water at the bottom of the duct is pushed through the flexible pipe that is attached to the condenser's copper tubes by a submersible pump. Water is sprayed onto the copper tubes via holes drilled into the flexible pipe's bottom side. It absorbs the heat emitted by the heated refrigerant. As a consequence, the water evaporates, the refrigerant cools, and the refrigerant changes phase, becoming a liquid refrigerant. Subcooling of refrigerant after the condenser increases the Refrigeration Effect and COP of the system in a Vapour Compression Refrigeration System. The condenser and evaporator outlet pipes are positioned in a heat exchanger to achieve this subcooling. The hot refrigerant flows into the condenser, while the 
low temperature vapour refrigerant flows into the evaporator. The heat transfer occurs from the hot liquid refrigerant to the vapour refrigerant because both are made to have indirect contact in the heat exchanger. As a consequence, the liquid refrigerant at the condenser's end is subcooled, and its condition falls below the liquid line of saturation. As a result, the cooling effect is enhanced. A heat exchanger is positioned between the condenser and the evaporator to accomplish the subcooling process at the compressor's end. The heat exchanger passes via the condenser exit pipe, which carries high temperature liquid refrigerant, and the evaporator exit pipe, which carries low-temperature vapour refrigerant. Heat is transferred from hightemperature liquid refrigerant to low temperature vapour refrigerant due to the temperature differential between them. The heat exchanger is insulated with foam to restrict heat transfer into and out of the system.

Net refrigeration effect $(\mathrm{NRE})=\mathrm{h}_{1}-\mathrm{h}_{4} \mathrm{~kJ} / \mathrm{kg}$

Mass flow rate to obtain 1TR, $\mathrm{mf}=210 \mathrm{NRE} \mathrm{kg} / \mathrm{min}$

Compressor work, $\mathrm{W}_{\mathrm{c}}=\mathrm{h}_{2}-\mathrm{h}_{1} \mathrm{~kJ} / \mathrm{kg}$

Heat rejection in the condenser $=h_{2}-h_{3} \mathrm{~kJ} / \mathrm{kg}$

Coefficient of Performance $(\mathrm{COP})=\left(\mathrm{h}_{1}-\mathrm{h}_{4}\right) /\left(\mathrm{h}_{2}-\mathrm{h}_{1}\right)$

Heat Equivalent for work of compression per 1TR, $\left(\mathrm{H}_{\mathrm{e}}\right)=\mathrm{m}_{\mathrm{f}} \mathrm{x}(\mathrm{h} 2-\mathrm{h} 1) \mathrm{kJ} / \mathrm{min}$

Theoretical power consumption $=\mathrm{H}_{\mathrm{e}} / 60 \mathrm{~kW}$

Compression pressure ratio:

Discharge pressure/ Suction pressure $=\mathrm{P}_{2} / \mathrm{P}_{1}$

Heat rejection ratio:

Heat rejection / Heat absorption $=\left(\mathrm{h}_{2}-\mathrm{h}_{3}\right) /\left(\mathrm{h}_{1}-\mathrm{h}_{4}\right)$

\section{RESULTS AND DISCUSSION}

\section{- Comparison of Coefficient of Performance}

comparison of the Coefficient of Performance (COP) for R134a refrigerant with and without an Evaporative Condenser and Heat Exchanger is shown in the Fig 1. Finally, it is concluded that the COP for utilising R134a in conjunction with an Evaporative Condenser is higher than for using a domestic refrigerator which was expected due to its high heat transfer capability. The coefficient of performance in the evaporative condenser of VCRS(C) with R-134a is 4.61 and VCRS without evaporative condenser(A) is 3.8. COP of R134a with the normal condenser is 4.2

\section{- Comparison of Refrigeration Effect (kJ/kg)}

The graph above shows a comparison of the Refrigeration effect for R134a refrigerant with and without an Evaporative Condenser and Heat Exchanger in conjunction with and without a heat

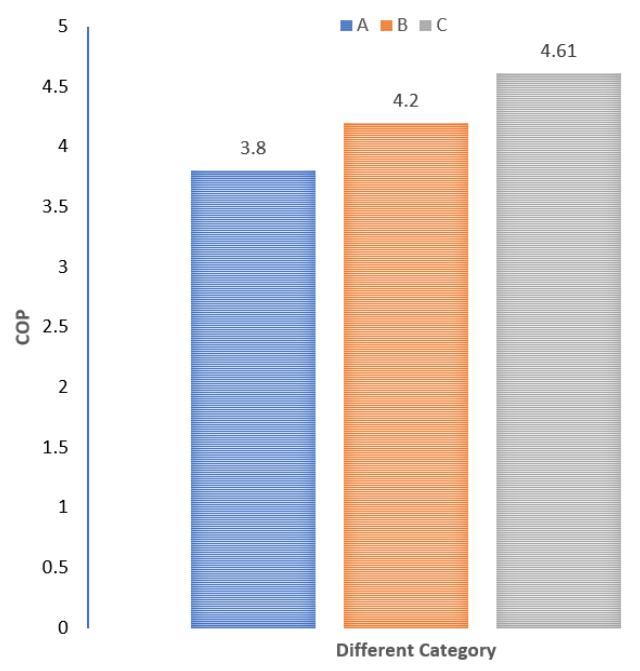

Fig 1: COP of different categories

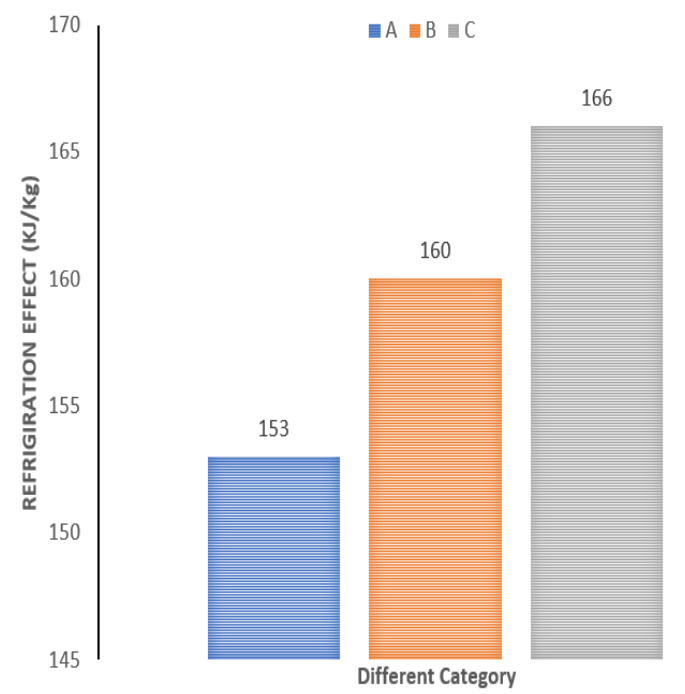

Fig 2: Refrigeration effect of different categories exchanger. From the Fig 2, it can be concluded that the refrigeration impact of utilising R134a with an Evaporative Condenser is greater than the refrigeration effect of a domestic refrigerator, which utilises an air-cooled conventional compressor to chill the refrigerator. The Refrigeration effect produced by R134a with Evaporative condenser is $5 \%$ more than that of $\mathrm{R} 134 \mathrm{a}$ with the normal condenser and also the evaporative condenser with heat exchanger has $9 \%$ more refrigeration effect produced than that of Domestic refrigerator. An additional heat exchanger may be added to the evaporative condenser, as illustrated in the graph below. This will further improve efficiency even more. 


\section{International Journal of Engineering Applied Sciences and Technology, 2021 \\ Vol. 6, Issue 3, ISSN No. 2455-2143, Pages 204-206 \\ Published Online July 2021 in IJEAST (http://www.ijeast.com)}

\section{- Comparison of Compressor work ( $\mathrm{kJ} / \mathrm{min})$}

The graph below in Fig 3 depicts the comparison of compressor work for R134a refrigerant with and without an Evaporative Condenser, as well as the comparison of compressor work for R134a refrigerant with and without a Heat Exchanger. Because of the subcooling of the refrigerant, the compressor's workload is reduced even more. The graph demonstrates that the compressor work in the home refrigerator or basic cycle necessitates a greater amount of effort than the compressor work in the other modified cycles. The Power consumption of the Compressor in the evaporative condenser of the VCRs system is $9.7 \%$ lower than the R134a with a usual condenser and also the evaporative condenser with heat exchanger is $17.4 \%$ lower than that of the domestic refrigerator.

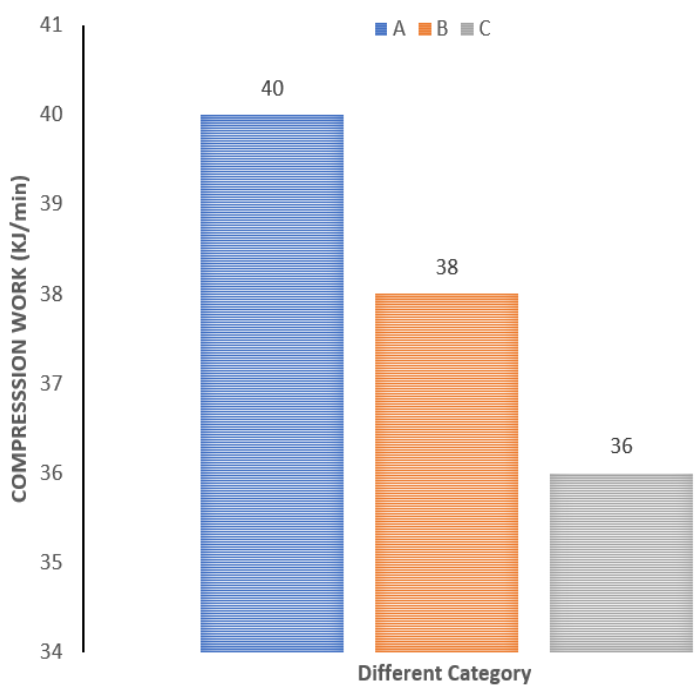

Fig 3: Compression work of different categories

\section{CONCLUSIONS}

Performance analysis is conducted on the domestic refrigerator of 165 litters capacity with evaporative condenser system using R-134a and also with a Heat exchanger in between the condenser and evaporator for subcooling and superheating. After, the experimental analysis carried out the following results can be concluded:

a. The coefficient of performance in the evaporative condenser of VCRS with R-134a is higher (4.61) than that of VCRS without evaporative condenser (3.8).

b. The Power consumption of the Compressor in the evaporative condenser of the VCRs system is $9.7 \%$ lower than the R134a with a usual condenser and also the evaporative condenser with heat exchanger is $17.4 \%$ lower than that of the domestic refrigerator. c. The Refrigeration effect produced by R134a with Evaporative condenser is 5\% more than that of R134a with the normal condenser and also the evaporative condenser with heat exchanger has $9 \%$ more refrigeration effect produced than that of Domestic refrigerator.

d. The Percentage of Power savings of R134a with evaporative condenser is $9.7 \%$ and the evaporative condenser with heat exchanger is $17.4 \%$ when these are compared to that of the Domestic refrigerator.

\section{REFERENCES}

1. Fiorentino M., Starace G. Numerical and Experimental Performance Analysis of Evaporative Condensers. Energy Procedia. 2016; 101: 26-33.

2. Holman J.P. Heat Transfer, Fifth ed., McGrawHill, 1981.

3. P. Saji Raveendran, Exergy analysis on domestic refrigeration the system with brazed plate heat exchanger as condenser',

Journal of thermal analysis and calorimetry, 127 (2017), 2439-2446.

4. Brown W.K., Fundamental concepts integrating evap0rative techniques in HVAC systems, ASHRAE Transactions 1990; 96 (Part1):1227-35.

5. Hwang Y, Radermacher R, Kopko W. An experimental evaluation of a residential-sized evaporatively cooled condenser.

6. Arora CP, Refrigeration and air conditioning, 2nd ed. McGraw-Hill, New Delhi, 2000.

7. ASHRAE, HVAC Systems and Equipment Handbook. ASHRAE Inc... Atlanta.GA,2008.

8. Hajida valloo E. Application of evaporative cooling on the condenser of window air conditioner. Journal of Applied Thermal Engineering 2007; 27:1937-43 